\title{
Preliminary Assessment of Physicochemical Properties of Borehole Water in the vicinity of Public Health Facilities in Nasarawa State, Nigeria
}

\author{
B.W. Tukura ${ }^{1 *}$, E. G. Ibrahim ${ }^{2}$, E. U. Onche ${ }^{3}$, M. A. G. Ibrahim ${ }^{3}$ \\ ${ }^{I}$ Departmentof Chemistry, Faculty of Natural and Applied Sciences, Nasarawa State University, Keffi, Nigeria \\ ${ }^{2}$ Nasara Spring Water, Nigeria Limited, Markurdi Road, Lafia, Nasarawa state, Nigeria \\ ${ }^{3}$ Department of Chemistry, College of Education Akwanga, P.M.B 05, Nasarawa state, Nigeria
}

\begin{abstract}
Water samples were collected from boreholes in the vicinity of public health facilities in Nasarawa State, Nigeria, for the evaluation of physicochemical parameters, using standard methods. Water $\mathrm{pH}$ from Keana was acidic (6.01-6.91), except at Chiata (9.34). pH values at Kuru (10.15) in Toto, Zalli (10.61) in Wamba, MCWC Obi (10.03) at Obi and Jangwa (10.31) in Awe were above the World Health Organization (WHO) permissible limits, so also nitrate contents in Ayele (11.04 mg/l) at Nasarawa, Chiji $(12.14 \mathrm{mg} / \mathrm{l})$ in Toto, Karmo (12.14 mg/l) in Toto, Main Market (12.02 mg/l) at Keffi, Sabo Gari (12.04 mg/l) at Keffi, Angiri $(12.06 \mathrm{mg} / \mathrm{l})$ in Lafia, Ugah $(13.02 \mathrm{mg} / \mathrm{l})$ in Lafia, and Agwa Sule $(13.05 \mathrm{mg} / \mathrm{l})$ in Obi. The highest and the lowest conductivity $(E C)$ values were recorded in borehole water from Nasarawa and Kokona respectively, while the highest phosphate content was recorded at Agyemo in Doma. The hardness level of water was highest at Karu and lowest in Doma, while alkalinity at Toto was highest, and lowest in Keffi. TDS, EC, alkalinity and total hardness levels were within the acceptable WHO and Standard Organization of Nigeria (SON) standards for ground water, which suggested that water from the boreholes were safe.
\end{abstract}

Keywords: Physicochemical properties, borehole, water, health facilities, Nasarawa state

\section{Introduction}

The pollution of groundwater has become a major environmental issue, particularly where groundwater represents the main source of drinking water [1-3]. This situation is so common in many lesser developed countries that the security of drinking water supply has been chosen as one of the ten Millennium Development Goals [4].

The challenge of ensuring usable water in sufficient quantities to meet the needs of human and ecosystems emerged as one of the primary issues of the 21 st century [5-6]. Inadequate water supply and poor water quality give rise to health and other societal issues, limit agricultural productivity and economic prosperity, and pose national security risk in some countries [7-9]. Problem of this nature have been increasing in scope, frequency, and severity because the demand for water continue to grow while supply of renewable water remain fixed [8].

Water is one of the most important resources with great implications for African development; however, the freshwater situation in Africa is unfortunately not encouraging. Presently, it is estimated that more than 300 million people in Africa live in a water-scarce environment [10-11]. The situation is getting worse as a consequence of population growth, rapid urbanization, increasing agriculture and industrial activities, and lack of adequate capacity to manage freshwater resources $[10,12]$. The growing deficit of good quality water in developing countries has spurred the need to utilize other sources of water other than conventional treated waters at maximal risk of microbiological and chemical pollution [13-14].

The quality of groundwater is affected by the characteristics of the media through which the water passes on its way to the groundwater zone of saturation [15-16]. The greater part of the soluble constituents in ground water comes from soluble minerals in soils and sedimentary rocks. The more common soluble constituents include calcium, sodium, bicarbonate and sulphate ions. Another common constituent is chloride ion derived from intruded evapotranspiration concentrating salts, and sewage wastes [17].

The major sources of pollution in underground water arises from anthropogenic activities, largely caused by the poor and uncultured living habit of people as well as the unhealthy practices of some health facilities, factories, industries and agricultural practices; resulting in the discharge of effluents and untreated wastes. Disinfectants, pharmaceuticals, radionuclides and solvents are widely used in health facilities which combine with hospital influents and may be leached into the underground water system [3, 18]. Ground water pollution could be avoided when borehole wells are located far from any source of potential pollution [2].

Borehole water serves as the major source of drinking water in the local population of Nigeria, since only very few can afford and rely on purified and treated bottled water for consumption [2]. Water is drawn from the ground for a variety of uses, principally community water supply farming (both livestock and irrigated 
cultivation) and industrial processes. Unlike surface water, groundwater is rarely used in situ for nonconsumptive purposes such as recreation and fisheries, except occasionally where it comes to the surface as springs.

Studies on groundwater pollution have been carried out in different parts of Nigeria [2-9]. Monitoring the quality of water is very essential for environmental safety, thus physicochemical parameters were determined in water from boreholes in the vicinity of some selected public health clinics (PHC) in thirteen (13) local government areas of Nasarawa state, Nigeria, to ascertain the quality of the water for various purposes.

\section{Material And Methods}

\subsection{Study Area}

Nasarawa state (Fig. 1) is located centrally in the middle belt region and lies between latitude $7^{\circ} 45^{\prime}$ and $9^{\circ} 25 \mathrm{~N}^{\prime}$ of the equator and between longitude $7^{\circ}$ and $9^{\circ} 37^{\prime} \mathrm{E}$ of the Greenwhich meridian. It shares boundary with Kaduna state in the north, Plateau state in the east, Taraba and Benue states in the south, and flanked by Kogi and Federal Capital Territory in the west [19].

\subsection{Sample collection and analysis}

Borehole water was sampled from sixty nine (69) boreholes located in some PHC in thirteen (13) local government councils of Nasarawa state (Fig. 1). The water samples were collected from the boreholes into prewashed two litres polythene containers (Tukura et al., 2012) and transported to the laboratory, treated and preserved for analysis. The physicochemical parameters were determined according to standard methods [20].

\subsection{Statistical analysis}

Simple statistics such as average and mean were used in the presentation of data. Values in each table are the average values for a given site, whereas the mean values of the physicochemical parameters for each local government area were presented in the form charts.

\section{Results And Discussion}

Variations in physicochemical parameters for borehole water form Karu, Kokona and Keffi are presented in Table 1. $\mathrm{pH}$ ranged between 7.79 and 8.36 at Karu, 7.41 to 8.15 for Kokona and 7.44 to 8.87 at Keffi. The highest $\mathrm{pH}$ (8.87) was recorded at Main Market at Keffi, and the lowest (7.74) at Arusu in Kokona. EC varied from from $95-203 \mu \mathrm{S} / \mathrm{cm}$ at Karu, $93-143 \mu \mathrm{S} / \mathrm{cm}$ (Kokona) and $130-145 \mu \mathrm{S} / \mathrm{cm}$ at Keffi. TDS at Karu varied from $43-101 \mathrm{mg} / 1,18-32 \mathrm{mg} / \mathrm{l}$ and $26-28 \mathrm{mg} / \mathrm{l}$ at Kokona and Keffi respectively. EC and TDS levels were highest in Gurku and Saka, both at Karu. Alkalinity varied in the areas as follows: 18 - 36 $\mathrm{mgCaCO}_{3} / 1$ (Karu), $18-32 \mathrm{mgCaCO}_{3} / 1$ (Kokona) and $26-28 \mathrm{mgCaCO}_{3} / 1$ (Keffi). Nitrate and chloride contents varied from 7.34 to $10.04 \mathrm{mg} / \mathrm{l}$ and 80 to $120 \mathrm{mg} / \mathrm{l}$ respectively at Karu, $80-100 \mathrm{mg} / \mathrm{l}$ and $18-35 \mathrm{mg} / \mathrm{l}$ at Kokona. Higher nitrate $(12.04 \mathrm{mg} / \mathrm{l})$ and chloride $(120 \mathrm{mg} / \mathrm{l})$ contents in Keffi were recorded at Sabo Gari and Main market areas respectively. Sulphates ranged from $30-55 \mathrm{mg} / \mathrm{l}$ in Karu, $18-55 \mathrm{mg} / \mathrm{l}$ at Kokona and between $35-44 \mathrm{mg} / \mathrm{l}$ at Keffi. Highest phosphate level $(0.04 \mathrm{mg} / \mathrm{l})$ was reported at Karu and Kokona, and below detectable limit in other sampling areas.

Physicochemical parameters results for borehole water from Nasarawa and Toto (Table 2) indicated that $\mathrm{pH}$ varied from 8.10 to 8.36 for Nasarawa and 6.90 to 10.15 at Toto.Highest EC levels were recorded at Ayele $(220 \mu \mathrm{S} / \mathrm{cm})$ in Nasarawa and Sabo $(240 \mu \mathrm{S} / \mathrm{cm})$ in Toto.TDS ranged from $94-111 \mathrm{mg} / \mathrm{l}$ at Nasarawa, and $50-121 \mathrm{mg} / \mathrm{l}$ in Toto. Variation in alkalinity was $18-36$ and $16-30 \mathrm{mgCaCO}_{3} / 1$ at Nasarawa and Toto respectively. Results for physicochemical parameters for Akwanga, N/Eggon and Wamba are reported in Table 3.The highest and the lowest water $\mathrm{pH}$ was recorded at Zalli (10.61) and Wayo (5.91) respectively, both at Wamba. EC ranged between $45-235 \mu \mathrm{S} / \mathrm{cm}$ at Akwanga, $65-185 \mu \mathrm{S} / \mathrm{cm}$ for $\mathrm{N} /$ Eggon and $83-224$ at Wamba. The lowest TDS contents were recorded at Nidan (43mg/l) in Akwanga, $31 \mathrm{mg} / \mathrm{l}$ at Ogba (N/Eggon) and $41-31 \mathrm{mg} / \mathrm{l}$ in Kwabe at Wamba. Alkalinity varied from $20-24 \mathrm{mgCaCO}_{3} / 1$ at Akwanga, $16-30$ $\mathrm{mgCaCO}_{3} / 1$ (N/Eggon), and $18-24 \mathrm{mgCaCO}_{3} / \mathrm{l}$ at Wamba, while nitrate ranged from $5.65-10.04 \mathrm{mg} / \mathrm{l}$ (Akwanga), $4.47-7.25 \mathrm{mg} / \mathrm{l}(\mathrm{N} /$ Eggon) and $5.45-9.24 \mathrm{mg} / \mathrm{l}$ at Wamba.

The lowest chloride content $(160 \mathrm{mg} / \mathrm{l})$ was obtained at Kwabe (Wamba) and the highest $(180 \mathrm{mg} / \mathrm{l})$ at Galle South in N/Eggon. At Akwnga, chloride levels varied between $80-160 \mathrm{mg} / 1,28-40 \mathrm{mg} / \mathrm{l}(\mathrm{N} / \mathrm{Eggon})$ and $22-38 \mathrm{mg} / \mathrm{l}$ at Wamba. Sulphate ranged from $30-60 \mathrm{mg} / 1$ (Akwnaga), $28-40 \mathrm{mg} / \mathrm{l}$ (N/Eggon) and $22-38$ $\mathrm{mg} / \mathrm{l}$ (Wamba). The highest phosphate level $(0.18 \mathrm{mg} / \mathrm{l})$ was recorded at Ogba (N/Eggon). Sulphate $(43 \mathrm{mg} / \mathrm{l})$ and chloride $(160 \mathrm{mg} / \mathrm{l})$ contents were both recorded at Ayele in Nasarawa. Table 4 reported results from Lafia and Obi. At Lafia, pH ranged from, $6.05-9.06$, EC: $65-216 \mu \mathrm{S} / \mathrm{cm}$, TDS: $32-104 \mathrm{mg} / 1$, alkalinity: $18-32$ $\mathrm{mg} / \mathrm{l}$,

nitrate: $6.77-12.06 \mathrm{mg} / \mathrm{l}$, chloride: $60-160 \mathrm{mg} / \mathrm{l}$, and sulphate: $17-45 \mathrm{mg} / \mathrm{l}$. At Obi, the highest water $\mathrm{pH}$ (10.03) and EC $(260 \mu \mathrm{S} / \mathrm{cm})$ level were recorded at MCWC Obi and Agwa Sale respectively, while chloride 
varied from $31-130 \mathrm{mg} / \mathrm{l}$ and $16-26 \mathrm{mg} / \mathrm{l}$ for alkalinity. The highest nitrate $(13.5 \mathrm{mg} / \mathrm{l})$ and chloride (180 $\mathrm{mg} / \mathrm{l}$ ) levels were obtained at Agwa Sule. Sulphate ranged from $28-75 \mathrm{mg} / \mathrm{l}$. Phosphate levels were generally low in all the areas.

From Table 5, pH varied between 7.85 and 10.31 (Awe), 5.31 and 7.89 (Doma), and from 6.01 to 6.91 at Keana. The lowest $(74 \mu \mathrm{S} / \mathrm{cm})$ and the highest $(261 \mu \mathrm{S} / \mathrm{cm})$ EC values were recorded at Alwaza (Doma) and Akuri (Awe) respectively. TDS ranged from $33-130 \mathrm{mg} / \mathrm{l}$ (Awe), $35-103 \mathrm{mg} / \mathrm{l}$ (Doma) and $67-11 \mathrm{mg} / \mathrm{l}$ at Keana. Alkalinity varied from $18-30$ at Awe, $10-20$ for Doma, and $14-20 \mathrm{mg} / \mathrm{l}$ at Keana. Nitrate levels were highest at Jangwa (Awe) and lowest (3.02) at Owena (Keana).

Chloride and sulphate varied respectively from $25-140 \mathrm{mg} / \mathrm{l}$ and $25-54 \mathrm{mg} / \mathrm{l}$ at Awe, $80-180 \mathrm{mg} / \mathrm{l}$ and $14-55 \mathrm{mg} / 1$ at Doma, $160-180 \mathrm{mg} / 1$ and $11-35 \mathrm{mg} / \mathrm{l}$ at Keana. The highest phosphate content was recorded at Agyemo in Doma. Fig. 2 shows the mean variations in $\mathrm{pH}$ of the borehole water. $\mathrm{pH}$ of the studied areas varied from slightly to moderately alkaline, except at N/Eggon and Doma where the water samples were slightly acidic $(<7)$.Variations in EC (Fig. 3) indicated that Karu, Nasarawa, Keana and Obi recorded relatively higher values. In comparison, EC values from Toto and Akwanga, and Lafia and Awe were similar. The highest and the lowest EC values were recorded in boreholes water in the vicinity of public health facilities from Nasarawa and Kokona respectively.

Variations in TDS (Fig. 4) show that TDS levels at Nasarwa, Keana and Obi were higher. Relatively low TDS contents were reported at Kokona, and N/Eggon. TDS levels at Keffi, Wamba, Awe and Doma did not show any significant variation. Nasarawa and Kokona recorded the highest and lowest TDS contents respectively.

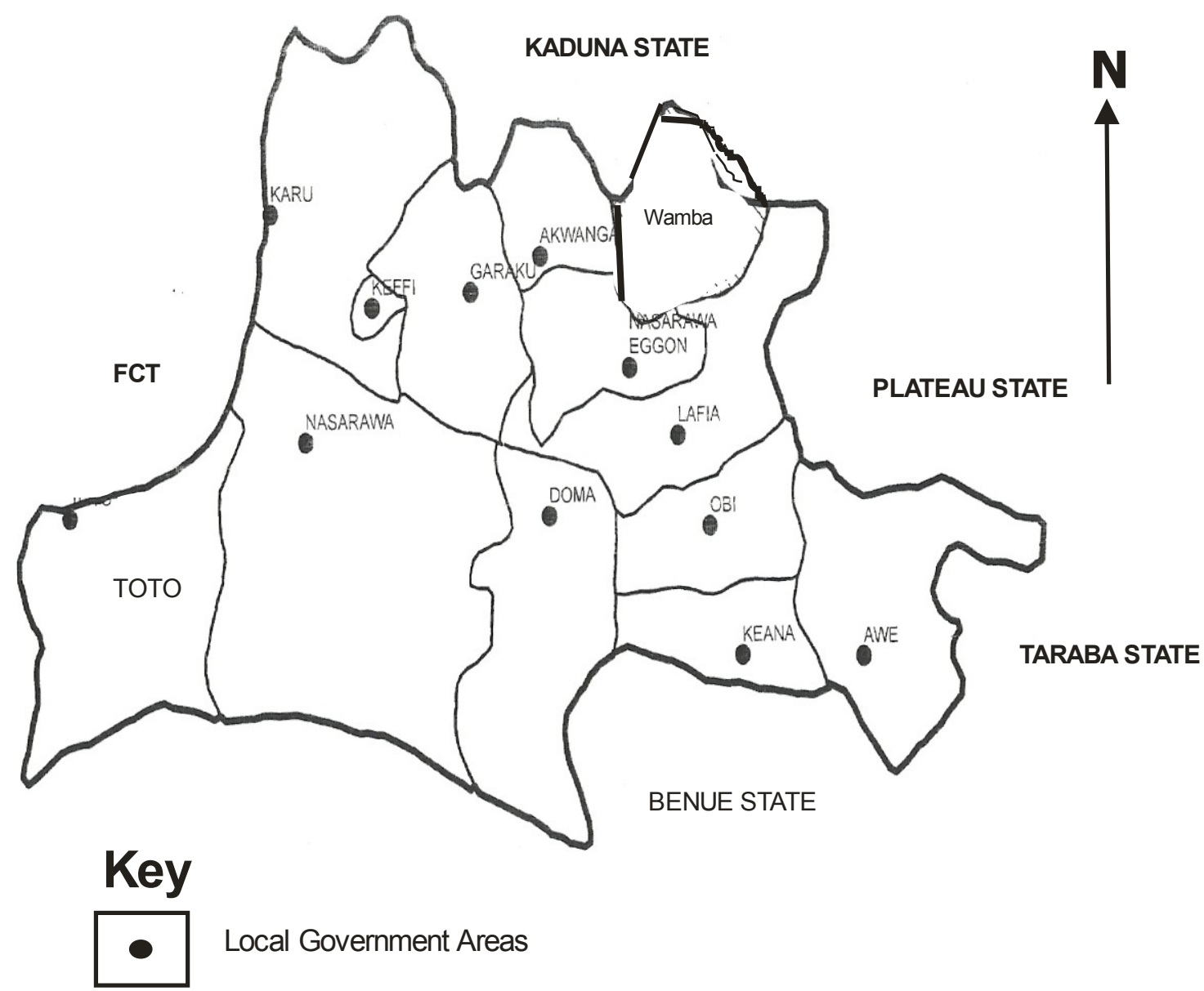

Fig. 1: Nasarawa State showing sampling areas 
Table1. Physicochemical properties of borehole water in Karu, Kokona and Keffi public health facilities.

\begin{tabular}{|c|c|c|c|c|c|c|c|c|}
\hline Areas & $\mathrm{pH}$ & $\begin{array}{c}\text { EC } \\
(\mu \mathrm{S} / \mathrm{cm})\end{array}$ & $\begin{array}{l}\begin{array}{l}\text { TDS } \\
(\mathrm{mg} / \mathrm{l}\end{array} \\
)\end{array}$ & $\begin{array}{l}\text { Alkal. } \\
\left(\mathrm{CaCO}_{3} / \mathrm{l}\right)\end{array}$ & $\begin{array}{l}\mathrm{NO}_{3}^{-} \\
(\mathrm{mg} / 1 \\
)\end{array}$ & $\begin{array}{l}\mathrm{Cl}^{-} \\
(\mathrm{mg} / \mathrm{l} \\
)\end{array}$ & $\begin{array}{l}\mathrm{SO}_{4}{ }^{2-} \\
(\mathrm{mg} / 1 \\
)\end{array}$ & $\begin{array}{l}\mathrm{PO}_{4}{ }^{2-} \\
(\mathrm{mg} / \mathrm{l})\end{array}$ \\
\hline \multicolumn{9}{|l|}{ Karu } \\
\hline New Karu & 8.20 & 122 & 61 & 30 & 8.05 & 120 & 30 & 0.01 \\
\hline Gurku & 8.36 & 203 & 101 & 36 & 7.34 & 100 & 34 & ND \\
\hline Saka & 8.36 & 203 & 101 & 18 & 10.04 & 120 & 40 & 0.02 \\
\hline Karape & 7.79 & 95 & 43 & 3 & 7.34 & 100 & 34 & ND \\
\hline Kari & 8.11 & 180 & 91 & 20 & 10.00 & 80 & 55 & 0.04 \\
\hline \multicolumn{9}{|l|}{ Kokona } \\
\hline S/Gari & 8.15 & 93 & 45 & 32 & 8.15 & 100 & 55 & 0.01 \\
\hline M/Market & 6.68 & 143 & 73 & 20 & 12.02 & 160 & 18 & 0.04 \\
\hline Arusu & 7.44 & 96 & 45 & 18 & 6.28 & 80 & 42 & 0.02 \\
\hline \multicolumn{9}{|l|}{ Keffi } \\
\hline $\mathrm{S} /$ Gari & 7.44 & 130 & 63 & 26 & 12.04 & 100 & 35 & ND \\
\hline M/Market & 8.87 & 145 & 78 & 28 & 10.05 & 120 & 44 & ND \\
\hline
\end{tabular}

Names in bold: Local government areas, ND: Not detectable

Table 2. Physicochemical properties of borehole water in Nasarawa and Toto public health facilities.

\begin{tabular}{|c|c|c|c|c|c|c|c|c|}
\hline Areas & $\mathrm{pH}$ & $\begin{array}{l}\mathrm{EC} \\
(\mu \mathrm{S} / \mathrm{cm})\end{array}$ & $\begin{array}{l}\text { TDS } \\
(\mathrm{mg} / \mathrm{l})\end{array}$ & $\begin{array}{l}\text { Alkal. } \\
\left(\mathrm{CaCO}_{3} / 1\right)\end{array}$ & $\mathrm{NO}_{3}{ }^{-}(\mathrm{mg} / \mathrm{l})$ & $\begin{array}{l}\mathrm{Cl}^{-} \\
(\mathrm{mg} / \mathrm{l})\end{array}$ & $\begin{array}{l}\mathrm{SO}_{4}^{2-} \\
(\mathrm{mg} / \mathrm{l})\end{array}$ & $\begin{array}{l}\mathrm{PO}_{4}{ }^{2-} \\
(\mathrm{mg} / \mathrm{l})\end{array}$ \\
\hline \multicolumn{9}{|c|}{$\begin{array}{l}\text { Nasarawa } \\
\text { Zaka }\end{array}$} \\
\hline Bello & 8.34 & 190 & 94 & 18 & 9.67 & 100 & 30 & 0.02 \\
\hline Godlinic & 8.34 & 190 & 94 & 18 & 9.67 & 100 & 30 & 0.02 \\
\hline Ayele & 8.10 & 220 & 111 & 22 & 11.04 & 160 & 43 & 0.04 \\
\hline Onda & 8.36 & 203 & 101 & 36 & 7.34 & 100 & 34 & ND \\
\hline \multicolumn{9}{|l|}{ Toto } \\
\hline Ukya & 7.70 & 105 & 50 & 30 & 6.19 & 80 & 45 & 0.10 \\
\hline Umesha & 6.68 & 167 & 92 & 16 & 2.97 & 100 & 15 & 0.02 \\
\hline Chiji & 7.94 & 182 & 98 & 22 & 12.14 & 180 & 63 & ND \\
\hline $\begin{array}{l}\text { Karmo } \\
\text { Bugga }\end{array}$ & 8.02 & 60 & 19 & 20 & 12.14 & 80 & 38 & 0.05 \\
\hline Sabo & 6.90 & 240 & 121 & 20 & 9.05 & 160 & 30 & 0.03 \\
\hline Offu & 9.56 & 200 & 101 & 28 & 10.09 & 140 & 58 & 0.02 \\
\hline Kuru & 10.15 & 53 & 110 & 28 & 11.16 & 160 & 45 & 0.40 \\
\hline
\end{tabular}

Names in bold: Local government areas, ND: Not detectable

Table 3. Physicochemical properties of borehole water in Akwanga, Nsarawa Eggon and Wamba public health \begin{tabular}{llllllll}
\multicolumn{8}{c}{ facilities. } \\
\hline & EC & TDS & Alkal. & $\mathrm{NO}_{3}{ }^{-}$ & $\mathrm{Cl}^{-}$ & $\mathrm{SO}_{4}{ }^{2-}$ & $\mathrm{PO}_{4}{ }^{2-}$
\end{tabular}

\begin{tabular}{|c|c|c|c|c|c|c|c|c|}
\hline Areas & $\mathrm{pH}$ & $\begin{array}{l}\mathrm{EC} \\
(\mu \mathrm{S} / \mathrm{cm})\end{array}$ & $\begin{array}{l}\text { TDS } \\
(\mathrm{mg} / \mathrm{l})\end{array}$ & $\begin{array}{l}\text { Alkal. } \\
\left(\mathrm{CaCO}_{3} / \mathrm{l}\right)\end{array}$ & $\begin{array}{l}\mathrm{NO}_{3} \\
(\mathrm{mg} / \mathrm{l})\end{array}$ & $\begin{array}{l}\mathrm{Cl}^{-} \\
(\mathrm{mg} / \mathrm{l})\end{array}$ & $\begin{array}{l}\mathrm{SO}_{4} \\
(\mathrm{mg} / \mathrm{l})\end{array}$ & $\begin{array}{l}\mathrm{PO}_{4} \\
(\mathrm{mg} / \mathrm{l})\end{array}$ \\
\hline \multicolumn{9}{|l|}{ Akwanga } \\
\hline C/School & 8.05 & 77 & 38 & 20 & 10.01 & 120 & 48 & 0.06 \\
\hline Takpir & 7.86 & 218 & 108 & 20 & 10.04 & 100 & 30 & 0.04 \\
\hline Tidde & 6.23 & 235 & 117 & 22 & 5.81 & 80 & 40 & ND \\
\hline Anjida & 7.86 & 218 & 108 & 20 & 10.04 & 100 & 30 & 0.04 \\
\hline Nidan & 7.41 & 99 & 43 & 24 & 7.17 & 160 & 44 & ND \\
\hline Nunku & 9.05 & 115 & 53 & 28 & 5.65 & 120 & 35 & 0.01 \\
\hline Koko & 6.01 & 45 & 19 & 30 & 8.08 & 100 & 60 & ND \\
\hline
\end{tabular}

\begin{tabular}{|c|c|c|c|c|c|c|c|c|}
\hline \multicolumn{9}{|l|}{$\begin{array}{l}\text { N/Eggon } \\
\text { Galle }\end{array}$} \\
\hline South & 6.08 & 171 & 84 & 22 & 5.56 & 180 & 28 & ND \\
\hline $\begin{array}{l}\text { Langalaga } \\
\text { Kagbu }\end{array}$ & 6.00 & 77 & 38 & 18 & 7.13 & 100 & 30 & ND \\
\hline Error & 7.57 & 90 & 47 & 30 & 4.47 & 120 & 30 & ND \\
\hline
\end{tabular}




\begin{tabular}{lllllllll} 
Ogba & 6.38 & 65 & 31 & 16 & 7.25 & 80 & 40 & 0.18 \\
Angbiggah & 7.12 & 183 & 94 & 22 & 6.09 & 80 & 28 & 0.10 \\
Wamba & & & & & & & & \\
Zalli & 10.61 & 128 & 65 & 24 & 9.24 & 80 & 35 & 0.03 \\
Wayo & 5.91 & 101 & 50 & 18 & 7.30 & 120 & 22 & ND \\
Yashi & & & & & & & & \\
Madaki & 8.13 & 129 & 66 & 28 & 9.10 & 160 & 38 & ND \\
Kwabe & 8.23 & 83 & 41 & 20 & 5.45 & 60 & 30 & 0.03 \\
Wamba & & & & & & & & \\
Kurmin & 9.16 & 224 & 118 & 20 & 9.05 & 100 & 26 & 0.02 \\
\hline Names
\end{tabular}

Names in bold: Local government areas, ND: Not detectable

Table 4. Physicochemical properties of borehole water in Lafia, and Obi public health facilities.

\begin{tabular}{|c|c|c|c|c|c|c|c|c|}
\hline Areas & $\mathrm{pH}$ & $\begin{array}{l}\mathrm{EC} \\
(\mu \mathrm{S} / \mathrm{cm})\end{array}$ & $\begin{array}{l}\text { TDS } \\
(\mathrm{mg} / \mathrm{l})\end{array}$ & $\begin{array}{l}\text { Alkal. } \\
\left(\mathrm{CaCO}_{3} / \mathrm{l}\right)\end{array}$ & $\begin{array}{l}\mathrm{NO}_{3}^{-} \\
(\mathrm{mg} / \mathrm{l})\end{array}$ & $\mathrm{Cl}^{-}(\mathrm{mg} / \mathrm{l})$ & $\begin{array}{l}\mathrm{SO}_{4}{ }^{2-} \\
(\mathrm{mg} / \mathrm{l})\end{array}$ & $\begin{array}{l}\mathrm{PO}_{4}{ }^{2-} \\
(\mathrm{mg} / \mathrm{l})\end{array}$ \\
\hline \multicolumn{9}{|l|}{ Lafia } \\
\hline Ombi Poly & 9.06 & 166 & 83 & 26 & 7.52 & 60 & 25 & 0.02 \\
\hline Agyaragu Y & 7.23 & 216 & 104 & 18 & 6.77 & 160 & 40 & ND \\
\hline Angiri & 8.23 & 186 & 94 & 22 & 12.06 & 140 & 455 & ND \\
\hline Akunza & 6.45 & 154 & 76 & 20 & 10.12 & 140 & 50 & ND \\
\hline Ugah & 6.9 & 166 & 86 & 32 & 13.02 & 120 & 17 & 0.02 \\
\hline Takpa & 6.05 & 65 & 32 & 22 & 9.34 & 80 & 34 & 0.01 \\
\hline \multicolumn{9}{|l|}{ Obi } \\
\hline Ome & 9.24 & 170 & 97 & 26 & 7.85 & 60 & 28 & 0.08 \\
\hline U/suwababa & 6.13 & 167 & 83 & 18 & 7.54 & 120 & 75 & 0.02 \\
\hline MCWC Obi & 10.03 & 213 & 105 & 20 & 7.54 & 120 & 50 & ND \\
\hline Akpangwa & 7.12 & 65 & 31 & 20 & 8.12 & 80 & 34 & ND \\
\hline Idevi & 8.04 & 142 & 77 & 24 & 8.24 & 100 & 30 & ND \\
\hline Agyaragu & 7.36 & 191 & 98 & 18 & 9.05 & 100 & 41 & ND \\
\hline Agewu & 8.00 & 170 & 82 & 28 & 8.21 & 80 & 36 & 0.06 \\
\hline Akaleku & 7.00 & 120 & 61 & 20 & 10.01 & 160 & 30 & 0.04 \\
\hline Agwa Sule & 7.00 & 260 & 131 & 16 & 13.05 & 180 & 30 & 0.08 \\
\hline
\end{tabular}

Names in bold: Local government areas, ND: Not detectable

Table 5. Physicochemical properties of borehole water in Awe, Doma and Keana public health facilities.

\begin{tabular}{|c|c|c|c|c|c|c|c|c|}
\hline & $\mathrm{pH}$ & $\begin{array}{l}\mathrm{EC} \\
(\mu \mathrm{S} / \mathrm{cm})\end{array}$ & $\begin{array}{l}\text { TDS } \\
(\mathrm{mg} / \mathrm{l})\end{array}$ & $\begin{array}{l}\text { Alkal. } \\
\left(\mathrm{CaCO}_{3} / \mathrm{l}\right)\end{array}$ & $\begin{array}{l}\mathrm{NO}_{3}^{-} \\
(\mathrm{mg} / \mathrm{l})\end{array}$ & $\mathrm{Cl}^{-}(\mathrm{mg} / \mathrm{l})$ & $\begin{array}{l}\mathrm{SO}_{4}{ }^{2-} \\
(\mathrm{mg} / \mathrm{l})\end{array}$ & $\begin{array}{l}\mathrm{PO}_{4}{ }^{2-} \\
(\mathrm{mg} / \mathrm{l})\end{array}$ \\
\hline \multicolumn{9}{|l|}{ Awe } \\
\hline Gidan Ihumer & 8.34 & 130 & 64 & 18 & 7.02 & 120 & 40 & 0.03 \\
\hline Jangara & 7.85 & 70 & 33 & 24 & 10.02 & 140 & 43 & 0.06 \\
\hline Akuri & 6.85 & 261 & 130 & 26 & 9.12 & 25 & 25 & 0.02 \\
\hline Jangwa & 10.31 & 182 & 130 & 30 & 10.05 & 100 & 54 & 0.01 \\
\hline \multicolumn{9}{|l|}{ Doma } \\
\hline Agyemo & 7.29 & 169 & 101 & 10 & 6.45 & 160 & 40 & 0.22 \\
\hline Iwashi & 7.89 & 175 & 84 & 20 & 9.05 & 100 & 25 & 0.02 \\
\hline Alwaza & 6.63 & 74 & 35 & 20 & 8.13 & 80 & 55 & 0.01 \\
\hline Idadu & 6.72 & 78 & 36 & 10 & 6.12 & 180 & 14 & 0.14 \\
\hline Agyema & 5.31 & 225 & 113 & 16 & 7.15 & 120 & 33 & 0.30 \\
\hline \multicolumn{9}{|l|}{ Keana } \\
\hline Agbaragba & 6.01 & 194 & 111 & 18 & 6.12 & 100 & 11 & 0.15 \\
\hline Owena & 6.01 & 135 & 67 & 22 & 3.02 & 180 & 25 & 0.02 \\
\hline Chiata & 9.34 & 176 & 98 & 24 & 4.18 & 160 & 35 & ND \\
\hline Kalachi & 6.91 & 202 & 103 & 14 & 4.45 & 140 & 15 & ND \\
\hline
\end{tabular}

Names in bold: Local government areas, ND: Not detectable 


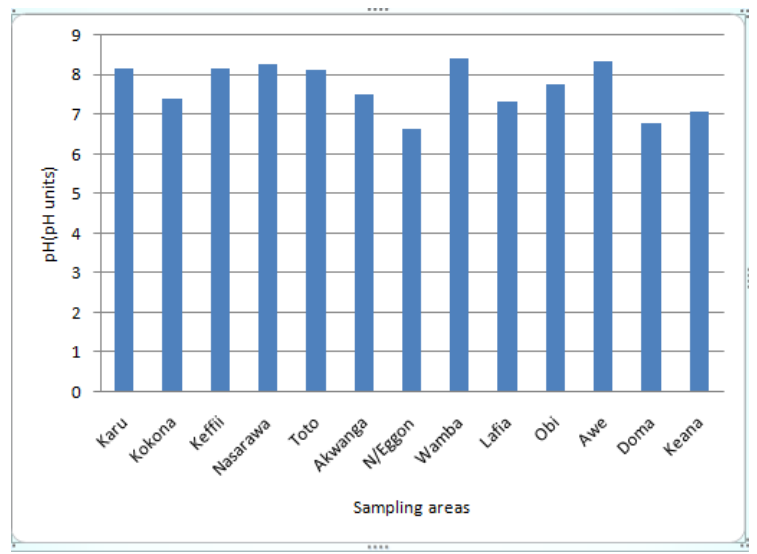

Figure 2 Variation in $\mathrm{pH}$ levels of borehole water

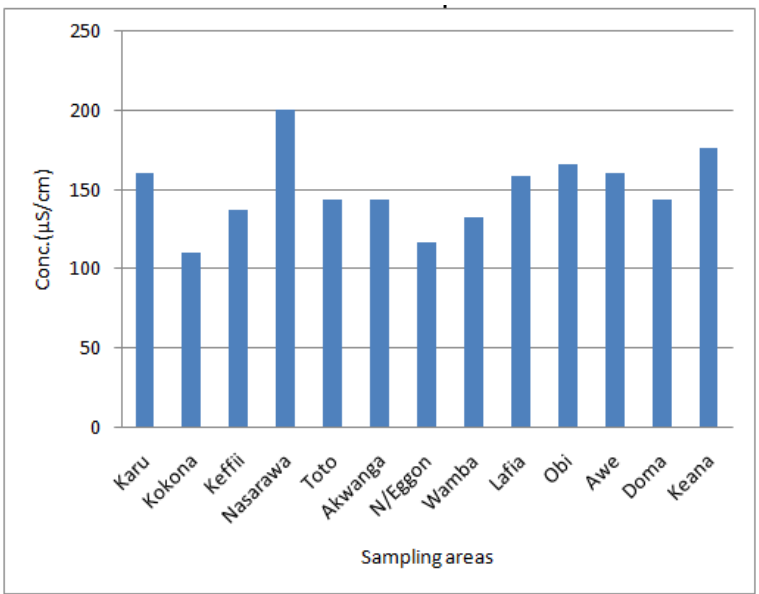

Figure 3 Variations in conductivity $(\mu \mathrm{S} / \mathrm{cm})$ of borehole water.

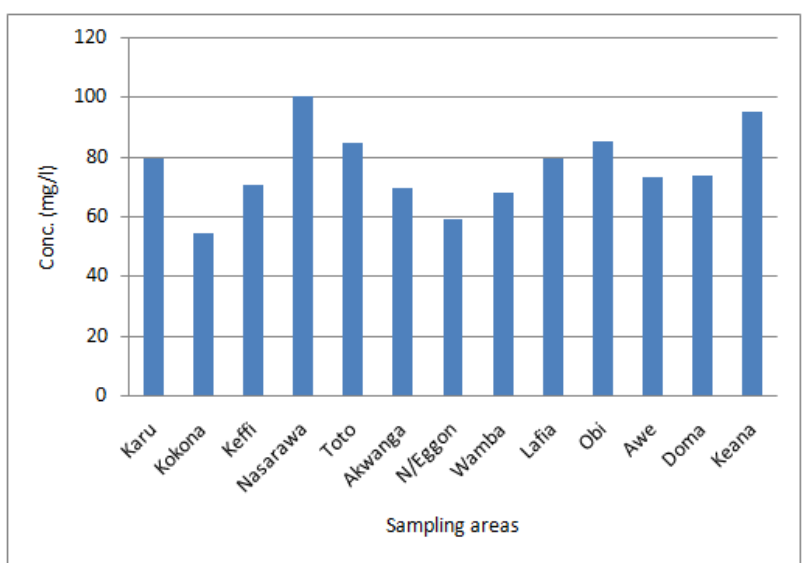

Figure 4 Variations in total dissolved solids (TDS) (mg/l) of borehole water

Mean variations in alkalinity and total hardness are shown in Fig. 5. Water hardness at Karu and Doma was highest and lowest respectively. Mean variation in alkalinity at Toto was significantly the highest and minimum at Keffi. Water hardness and alkalinity generally did not vary significantly across the areas.

From Fig. 6, nitrate contents were similar in all the studied areas and generally low. The highest and lowest chloride levels were observed at Keana and Akwanga respectively, and increases progressively from Karu to Toto, except at Keffi. Sulphate levels at Keffi, Toto, Awe and Obi were not significantly different. Sulphate levels in the borehole water were $<40$. Phosphate contents were generally low.

$\mathrm{pH}$ is an important indicator of water quality and the extent of pollution in the studied areas. Unpolluted rivers normally show near neutral or slightly alkaline $\mathrm{pH}$. $\mathrm{pH}$ of borehole water at Kuru (10.15), Zalli (10.61), MCWC Obi (10.03) and Jangwa (10.31) were higher than the WHO [21] accepted limit (9.20). Water pH levels were higher than the values reported by $[3,11,15]$, but within the same range of values reported by [22] for borehole water in Niger state Polytechnic, Zungeru campus. Conductance (EC) qualitatively reflects the status of 
inorganic pollution and is a measure of total dissolved solid and ionized species in the water. EC levels were higher than the values reported by [2,10], lower than the levels reported by [22]. Physicochemical parameters results for borehole water from Nasarawa and Toto (Table 2) indicated that $\mathrm{pH}$ varied from 8.10 to 8.36 for Nasarawa and 6.90 to 10.15 at Toto. EC values were, however within the WHO [21] acceptable limit $(500 \mu \mathrm{S} / \mathrm{cm})$.

The measure of total dissolved solids (TDS) is a good indicator of the mineralized character of the water. High levels of dissolved solids in the water systems increase the biological and chemical oxygen demand, which deplete the dissolve oxygen level in the aquatic system. TDS in drinking-water originate from natural sources, sewage, urban runoff and industrial wastewater [15].

The levels of TDS in abroad sense reflect the burden of aquatic systems [23].TDS of the studied borehole water were within the WHO acceptable limit $(500 \mathrm{mg} / \mathrm{l})$, but higher than the values reported by [11] for some selected boreholes in Umuahia North Local Government Area, in Abia State, and [10] for borehole water in Yenagoa, Bayelsa State, Nigeria. Water TDS contents fall within the range reported by [14] and [8] for borehole water in Okutukutu, Bayelsa State.

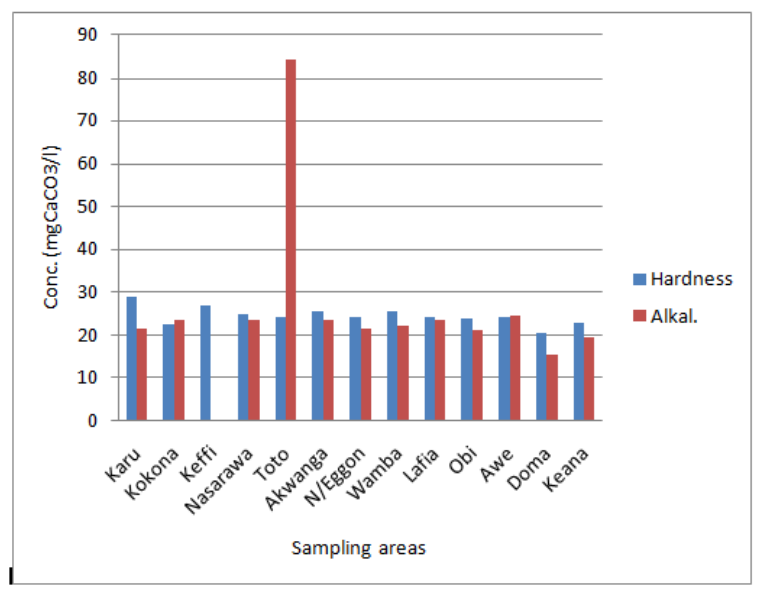

Figure 5 Variations in total hardness $\left(\mathrm{CaCO}_{3} / \mathrm{l}\right)$ and alkalinity $\left(\mathrm{CaCO}_{3} / \mathrm{l}\right)$ of borehole water

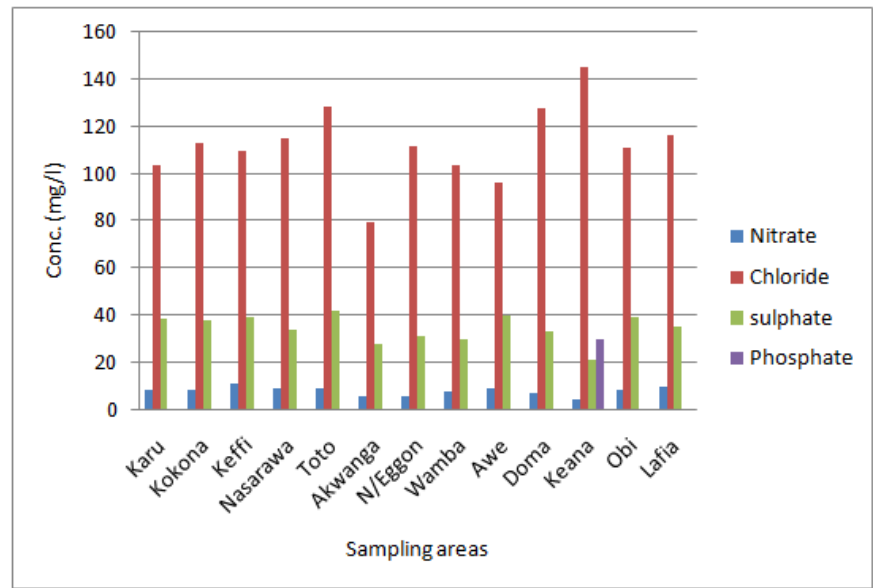

Figure 6 Variations in nitrate, chloride, sulphate and phosphate contents in borehole water

Chloride is present in nearly all natural water with varying concentration, depending on the geochemical condition of the area [23]. Chloride in drinking-water originates from natural sources, sewage and industrial effluents, urban runoff containing de-icing salt and saline intrusion. No health-based guideline value is proposed for chloride in drinking-water by WHO and SON standard of drinking water. However, chloride concentrations in excess of about $250 \mathrm{mg} / \mathrm{l}$ can give rise to detectable taste in water. Chloride levels in the borehole water were above the levels reported by [16], but within the range reported by [2, 22, 24].

Alkalinity and EC values in this study were higher than those reported by [10-11]. EC is an indicator of water quality and soil salinity, hence the relatively high values observed in some water samples showed high salinity; thus the waters might not be very suitable for domestic and agricultural use. The alkalinity of water may be caused by dissolved strong bases such as sodium or potassium hydroxide (and other hydroxide containing compounds), hydroxide ions are always present in water, even if the concentration is extremely small [16] 
Nitrate, the most highly oxidized form of nitrogen, is commonly present in surface and ground waters because it is the end product of the aerobic decomposition of organic nitrogenous matter. Some ground waters may also have nitrate contamination as a consequence of leaching from natural vegetation. Nitrates react directly with hemoglobin in human blood to produce methemoglobin, which destroys the ability of blood cells to transport oxygen. This condition is especially serious in babies under three months of age as it causes a condition known as methemoglobinemia or "blue baby"disease [3, 8]. Nitrate contents at Ayele (11.04 mg/l), Chiji $(12.14 \mathrm{mg} / \mathrm{l})$, Karmo (12.14 mg/l), Main Market (12.02 mg/l), Sabo Gari (12.04 mg/l), Angiri (12.06 $\mathrm{mg} / \mathrm{l})$, Ugah (13.02 mg/l), and Agwa sule (13.05 mg/l) were above the WHO [21] acceptable limit (10 mg/l). Nitrate levels of the studied areas were higher than the levels reported by [2,10,14], lower than the values reported by [8], but in agreement with the results reported by [11, 25].Sulphate levels were higher than the values reported by [2].

\section{Conclusion}

Physicochemical properties show some variations according to sampling areas. Water $\mathrm{pH}$ at Keana was acidic (6.01 - 6.91), except at Chiata (9.34); but alkaline at Kuru (10.15), Zalli (10.61), MCWC Obi (10.03) and Jangwa (10.31) in Awe. Variation in water $\mathrm{pH}$ may affect mobilisation of available heavy metals. At low $\mathrm{pH}$, heavy metals may be remobilised into the water column affecting water quality. Nitrate contents at Ayele (11.04 mg/l), Chiji (12.14 mg/l), Karmo (12.14 mg/l), Main Market (12.02 mg/l), Sabo Gari (12.04 mg/l), Angiri $(12.06 \mathrm{mg} / \mathrm{l})$, Ugah $(13.02 \mathrm{mg} / \mathrm{l})$ and Agwa Sule $(13.05 \mathrm{mg} / \mathrm{l})$ in Obi were above the World Health Organization (WHO) permissible limits. Nitrate can be a natural constituent but high concentration often implies a source of pollution. Farming activities should be regulated around such facilities, since the major source of nitrate might be from fertilizers applied to crops in farms close to boreholes, which is subsequently leached into the ground water. TDS, EC, alkalinity and total hardness levels were within the acceptable WHO and Standard Organization of Nigeria (SON) [25] standards for ground water, which suggested that the borehole water were safe for consumption, agriculture and industrial uses. The low level observed for some parameters may be attributed to low level of industrialization, lack of proximity to possible source of contaminants and possibly far reaching water table in the study areas. Variations in some physiochemical parameters suggest that there is the need for continuous monitoring of the borehole water quality, especially for heavy metal levels which may be affected by change in $\mathrm{pH}$. Microorganisms might also been responsible for the changes in water properties, thus the need for microbial analysis.

\section{References}

[1] O. Adeyemi, O. B. Oloyede and A.T. Oladiji, Physicochemical and microbial characteristics of leachate-contaminated groundwater, Asian Journal of Biochemistry, 2, 2007, 343-348.

[2] O.V. Akpoveta, B.E. Okoh and S.A. Osakwe, Quality assessment of borehole water used in the vicinities of Benin, Edo State and Agbor, Delta State of Nigeria. Current Research in Chemistry, 3, 2011, 62-69.

[3] I. Uffia Dan, F. E. Ekpo and D. E. Etim, Influence of heavy metals pollution in borehole water collected within abandoned battery industry, Essien Udim, Nigeria, Journal of Environmental Science and Water Resources, 2(1), 2013, 022-026.

[4] World Health Organisation (WHO), Meeting the MDG Drinking water and Sanitation: A midterm assessment of progress, (WHO/UNICEF, 2004)

[5] S. N. Rao, Seasonal variation of groundwater quality in a part of Guntur District, Andhra Pradesh, India. Environmental Geology, 49, 2006, 413-429.

[6] E. E. Obot and D. B. Edi, Spatial variation of borehole water quality with depth in Uyo municipality, Nigeria, International Journal of Environmental Science, Management and Engineering Research, 1(1), 2012, 1-9.

[7] O. E. Agbalagba, O. H. Agbalagba, C. P. Ononugbo and A. A. Alao, Investigation into the physico-chemical properties and hydrochemical processes of groundwater from commercial boreholes In Yenagoa, Bayelsa State, Nigeria. African Journal of Environmental Science and Technology, 5(7), 2011, 473-481.

[8] M. B. Nkamare, N. O. Anttoniette, and J. A. Afolayan, Physico-chemical and microbiological assessment of borehole water in Okutukutu, Bayelsa State, Nigeria, Advances in Applied Science Research, 3(5), 2012, 2549-2552.

[9] T. O. Stephen and K. A. Kennedy, Bacteriological profile and physico-chemical quality of ground water: A case study of bore hole water sources in a rural Ghanaian community, Inernational Journal of Microbiological science and Applied Science, 2(8), 2013, 21-40.

[10] T. A.Gordon and E. Ejenma, Groundwater Quality Assessment of Yenagoa and Environs Bayelsa State, Nigeria between 2010 and 2011, Resource and Environment, 2(2), 2012, 20 -29.

[11] E. C. Ukpong, B. B. Okon, Comparative analysis of public and private borehole water supply sources in Uruan LocalGgovernment Area of Akwa Ibom state, International Journal of Applied Science and Technology, 3(1), 2013, 76-91

[12] P.O. Agbaire, and I. P. Oyibo, Seasonal variation of some physic-chemical properties of borehole water in Abrake, Nigeria, African Journal of Pure and Applied Chemistry, 3(6), 2009, $116-118$.

[13] J. U. Iyasele and D. J. Idiata, Physio-chemical and Microbial Analysis of Boreholes water samples: A case of some boreholes in Edo North, Edo State, Journal of Emerging Trends in Engineering and Applied Sciences, 2(6), 2011, 1064-1067.

[14] A. T. Odeyemi, O. J. Akinjogunla and M. A. Ojo, Bacteriological, physicochemical and mineral studies of water samples from Artesian bore-hole, spring and hand dug well located at Oke-Osun, Ikere- Ekiti, Nigeria, Archives of Applied Science Research, 3(3), 2011, 94-108.

[15] O. Adeyemi, O.B. Oloyede and A.T. Oladiji, Physicochemical and microbial characteristics of leachate-contaminated groundwater, Asian Journal of Biochemistry, 2, 2007, 343-348 
[16] E. Bernard and N. Ayeni, Physicochemical analysis of groundwater samples of Bichi local government area of Kano State of Nigeria, World Environment, 2(6), 2012, $116-119$.

[17] D. Chapman, Water Quality Assessments - A Guide to use of biota, sediments and water in environmental monitoring, $\left(2^{\text {nd }} \mathrm{ed}\right.$. UNESCO/WHO/UNEP, J. Chilton Limited, 1996).

[18] E. D. Oruonye and W.O. Medjor, Physico-chemical analysis of borehole water in the three resettlement areas (Ali Sheriffti, Sagir and Dambore) in the Lake Chad Region of Nigeria. Nigerian Journal of Microbiology, 23(1), 2009, 1846-1851.

[19] N. D. Marcus and N. L. Binbol, Introduction and historical background, in Geographical perspective on Nasarawa state, (Onaive Printing and Pub. Co. Limited, Nigeria, 2007).

[20] American Public Health Association (APHA), Standard Method for the Examination of Water and Wastewater (American Water Works Association, Water Environment Federation, 1995).

[21] World Health Organization (WHO), Guidelines for drinking water quality (incorporating the $1^{\text {st }}$ and $2^{\text {nd }}$ Addenda Vol. 1 , Recommendations, 3rd ed, Geneva, 2008).

[22] A. Muhammad, B. T. S. Saidu, B. S. Ahmed, and S. A. Mohammed, Bacteriological and physico-chemical properties of borehole water in Niger state Polytechnic, Zungeru campus, Indian Journal of Science Research, 4(1), 2013, 1-6.

[23] B. W. Tukura, C. E. Gimba, I. G. Ndukwe and B. C. Kim, Physicochemical characteristics of water and sediment in Mada River, Nasarawa State, Nigeria, International Journal of Environment and Bioenergy, 1(3), 2012, 170-178.

[24] R.M. Shyamala, D.M. Shanti and O.P. Lalitha, Physicochemical analysis of borehole water samples of Telungupalayam area in Coimbatore District,Tamilnadu, India, E-Journal of Chemistry, 5(4), 2001, 924-929.

[25] Standards Organization of Nigeria (SON), Nigerian Standard for Drinking Water Quality (Abuja, Nigeria, 2007) 